Bajopas Volume 2 Number 2 December, 2009

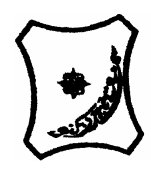

Bayero Journal of Pure and Applied Sciences, 2(2): 172 - 174

Received: June, 2009

Accepted: October, 2009

\title{
STUDY OF ICHTYOFAUNA OF DABERAM RESERVOIR, KATSINA STATE
}

\author{
${ }^{* 1}$ Bala U. ${ }^{1}$ Lawal I, ${ }^{2}$ Bolorunduro P.I., ${ }^{3}$ Oniye S.J. ${ }^{3}$ Abdullahi S.A. ${ }^{4}$ Bichi A.H. \\ ${ }^{1}$ Department of Biology, Umaru Musa Yaradua University, Katsina ${ }^{2}$ NAERLS, A.B.U. Zaria \\ ${ }^{3}$ Department of Biological Sciences, Ahmadu Bello University, Zaria \\ ${ }^{4}$ Department of Biological Sciences, Bayero University Kano \\ *Corresponding author
}

\begin{abstract}
Research was carried out to explore the fish species diversity and study some aspects of the Biology of fish of Daberam reservoir, Katsina state, for a period of three month from March to May 2009. 66 Samples of fish were collected from commercial fishermen and experimental fishing gears, preserved in formalin and taken to laboratory for identification. Seven genera comprising eleven species were identified. The regression coefficient (b) were 3.07, 2.91 and 3.21 for the three most commercially importance species in the reservoir i.e. Oreochromis niloticus, Tilapia zilli and Clarias gariepinus respectively, the results indicated Positive allometric growth for 0 . niloticus and C. gariepinus and negative allometric growth for T. zilli. The mean condition factor (k) was 1.140, with values of $1.027,1.660$, and 0.732 for 0 . niloticus, $T$. zilli and C. gariepinus respectively. This result indicates that the fish are not leaving well compared to other freshwater fishes.
\end{abstract}

Key words: Daberam reservoir, fishdiversity, allometric growth, condition factor

\section{INTRODUCTION}

The fish specie diversity, which is currently recognised worldwide, shows 25,000 species of which 10,000 species are found in freshwater ecosystem. Specialists estimated that at least 5,000 await discovery. Thus, freshwater fish discovery can serve as a platform of livelihood and biodiversity of conservation values. They serve as a source of protein and food for increasing human population in developing countries (www.fishbase.org).

Knowledge of quantitative aspects such as weightlength relationship, condition factor, growth, recruitment, and mortality of fishes is an important tool for the study of fishing biology, mainly when the species lies at the base of the higher food web. In fish, the factor of condition (K) reflects, through its variations, information on the physiological state of the fish in relation to its welfare. From a nutritional point of view, there is the accumulation of fat and gonadal development (Le Cren, 1951). From a reproductive point of view, the highest $K$ values are reached in some species (Angelescu et al., 1958). K also gives information when comparing two populations living in certain feeding, density, climate, and other conditions; when determining the period of gonadal maturation; and when following up the degree of feeding activity of a species to verify whether it is making good use of its feeding source (Weatherley, 1972).The study of the condition factor is thus important for understanding the life cycle of fish species and contributes to adequate management of these species and, therefore, to the maintenance of equilibrium in the ecosystem. (Lizama and Ambrosio, 2002)

The fisheries and fish resources of Nigeria are not only of considerable economic importance but they are also making a significant contribution to national food security and as well providing major sources of employment in rural areas. The fish stock diversities are directly dependant on the quality and quantity of water resources in the country. Nigeria is endowed with vast networks of rivers, streams, seasonally flooded plains, natural and man made reservoirs, as well as brackish waters in lagoons and coastal creeks, which form habitat for fish (Bolorunduro, 2003).

In sub Saharan Africa, fish accounts for roughly $10 \%$ of the animal protein consumed, and $98 \%$ of this is finfish (Delgado and McKenna, 1997). The average per capita consumption of fish in Africa in 1992 was about $8 \mathrm{~kg}$ per annum having increased from an average of $7 \mathrm{~kg}$ per annum from $1969-1974$ (Ahmed, 1997). Roughly $40 \%$ of fish consumption in Africa south of the Sahara is freshwater fish as compared to the global average of $25 \%$.while West Africa is a relatively large consumer of finfish. Per capita consumption has not grown over the last 20 years (Bonga, 1999).

\section{Study site}

Daberam reservoir is located between Daura and Dutsi local Government. It has a capacity of 12.5million cubic meters covering about 400 hectares of land but because of siltation only 200 hectares is now fully been utilize. The area has an annual rainfall of $600-640 \mathrm{~mm}$. The reservoir has Kigo and Riniyal rivers as its main source of water and Dannakola as its tributary. It has a crest length of 2377.44meters and its deepest point is 42.6 meters. The reservoir lies in the Sudan savannah zone between latitude $13^{\circ} 2^{\prime}$ and longitude $8^{\circ} 21^{\prime}$. The climate is characterized by distinct wet and dry season. 


\section{MATERIALS AND METHODS}

\section{Experimental fish sampling}

A fleet of gillnet made up of nine (9) multi filament nets of the following stretched mesh sizes where used.

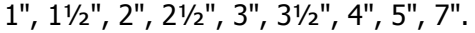

-To sample the shore, surface and bottom water of the reservoir.

-Each net measured 30m long and 3m deep.

-The nets was set at approximately 2 hours before sunset and lifted two hours after sun rise.

-Samples were collected fortnightly from both experimental fish sampling and artisanal fishery survey for a period of 3 month.

\section{Fish identification}

The fish were identified in the laboratory up to the species level with the aid of standard text such as Fish and Fisheries of Northern Nigeria, Reed et al. (1967), and 'Field guide to Nigerian freshwater fishes'. (Babatunde and Raji, 2004).

Weight-length relationship and condition factor. The parameters $a$ and $b$ of the length-weight relationship of the form: $W=a L b$ which was transformed in to logarithmic form $\log W=\log a+b(\log l)$ for the three most economic important species i.e. Oreochromis niloticus,
Tilapia zilli and Clarias gariepinus, were calculated. The condition factor was also calculated from the relationship: $\mathrm{k}=\mathrm{W} 100 / \mathrm{Lb}$.

\section{RESULTS AND DISCUSSIONS}

The mean weights were $82.6 \mathrm{~g}, 57.96 \mathrm{~g} ; 118.5 \mathrm{~g}$ while the mean length were $16.92 \mathrm{~cm}, 15.5 \mathrm{~cm}$ and $25.58 \mathrm{~cm}$ for $O$. niloticus, T. zilli, and C. gariepinus respectively.

After plotting a graph of In $\mathrm{W}$ against In $\mathrm{L}$ for $\mathrm{O}$. niloticus, the value of $b$ was found to be 3.07 , the $95 \%$ confidence interval for $b$ is $\{(3.07-0.154)(3.07+0.154)$ or $\{2.916,3.224\}$. for $T$. zilli the value of $b$ was found to be 2.91 , the $95 \%$ confidence limit is $\{(2.91-$ $0.146)(2.91+0.146)\}$ or $(2.764,3.056)$. The value of $b$ for Clarias gariepinus was found to be 3.21 , the $95 \%$ confidence limit is $\{(3.21-0.16)(3.21+0.16)\}$ or $(3.05,3.37)$. The mean value of $b$ coefficient for the three species studied was 3.06. This indicates a nearly isometric relationship with $60 \%$ of the variation in body weight being accounted for by changes in length. The $b$ value of 3.07 and 3.21 for 0 . niloticus, and $C$. gariepinus respectively compared to the mean value of 3.06 indicate positive allometric or proximate isometric growth. The $b$ value of 2.91 for $T$. zilli compared to the mean value however shows negative allometric growth.

Table 1: length-weight relationship and condition factor of 0 . niloticus, T. zilli and C. gariepinus at Daberam reservoir, Katsina state.

\begin{tabular}{lccccccc}
\hline Specie & Total length range $(\mathbf{c m})$ Weight range(g) & $\mathbf{n}$ & $\mathbf{a}$ & $\mathbf{b}$ & $\mathbf{k}$ & $\mathbf{r}$ \\
\hline O.niloticus & $14-21$ & $40-140$ & 22 & -1.1 & 3.07 & 1.027 & 0.79 \\
T. zilli & $11.3-20.5$ & $23-110$ & 22 & -1.2 & 2.91 & 1.660 & 0.93 \\
C.gariepinus & $17.8-43$ & $39-380$ & 22 & -2.2 & 3.21 & 0.732 & 0.60 \\
\hline
\end{tabular}

$\mathrm{n}=$ sample size, $\mathrm{a}=$ regression intercept, $\mathrm{b}=$ regression coefficient, $\mathrm{r}=$ correlation coefficient, $\mathrm{k}=$ condition factor

These confidence limits indicated that only the first decimal in the estimate of $b$ is significant, hence the true value of $b$ could as well be 3.0 .

Similar results were obtained for Chrysichthys walkeri (Ikusemiju, 1976), Chrysichthys nigrodigitatus (Fagade and Adebisi, 1979) and E. fimbriata (Ekeng, 1990). Abdurahman et al (2004) obtained median 2.85 and mode 3.0 values of $b$, while Abdallah (2002) recorded $b$ values of between 2.5 to 3.44 for the fishes studied in different marine bodies. According to Pauly and Gayanilo (1997), $b$ values may range from 2.5 to 3.5 suggesting that result of this study is valid. The condition factor is an index reflecting interactions between biotic and abiotic factors in the physiological condition of fishes. It shows the population's welfare during the various stages of the life cycle (Angelescu et al., 1958). The condition factor was calculated from the relationship: $\mathrm{k}=\mathrm{W} 100 / \mathrm{Lb}$ were found to be $1.027,1.660$, and 0.732 for 0 . niloticus, Tilapia zilli and Clarias gariepinus respectively. These values are lesser than the values of 2.9 to 4.8 documented by Bagenal and Tesch (1978) for mature fresh water fish fresh body weight. This indicates the fish are not leaving well compared to other freshwater fishes. The regression coefficient ' $r$ ' was $0.79,0.93$ and 0.60 for $O$. niloticus, $T$. nilotica and $C$. gariepinus.

The variations in fish sizes indicate that the fish population ranged from immature specimens to fully matured ones. This also suggests differences in their growth (Frota et al., 2004).

Seven (7) genera comprising eleven (11) species as indicated in table 2 were identified.

\section{Table 2: Distribution of fish species at Daberam reservoir}

\begin{tabular}{ll}
\hline GENUS & SPECIES \\
MORMYROPS & Petrocephalus bovei, Mormyrus rume \\
CHICHLIDAE & Oreochromis niloticus, Tilapia zilli, Sarotherondon galilaea. Tilapia guntheri \\
PROTEPTERUS & guntheri \\
SCHILBE & Protepterus annectins \\
LATES & Schilbe micropogon \\
CLARIDAE & Lates niloticus \\
ALESTES & Clarias gariepinus \\
\hline
\end{tabular}


The range and abundance of fish species can change dramatically due to climate change and they migrate to new locations. For economic security and achieving livelihood, a large scale intensive aquaculture practices in village ponds and reservoirs also affected native fish fauna. Dam constructions prevented fish migration to upstream and hence affect their breeding potential. The aquaculture of hybrid varieties also has severe impact on fish diversity. The run-off water from agriculture fields carries pesticides which result in fish mortality.

The intensive agricultural activities in the study site which resulted in washing of pesticides and other agro-chemical in to the reservoir coupled with constant draining of the water for irrigation purpose and lack of fishing regulation has resulted in the caught of only small fishes in the reservoir because they are hardly allowed to grow to any reasonable size.

\section{REFERENCES}

Abdallah M (2002). Length-weight relationship of fishes caught by trawl of Alexandria, Egypt. NAGA ICLARM Q. 25 (1): 19-20.

Abdurahiman KP, Harishnayak $T$, Zacharia PU,Mohamed KS (2004). Length-weight relationship of commercially important marine fishes and shellfishes of the southern coast of Karnataka, India. NAGAICLARM Q. 27 (1\&2): 9-14.

Adebisi AA (1979). On the fecundity of Chrysichthylys nigrodigitatus (Lacepede) of Asejire Dam, Oyo State, Nigeria. Nig J. Nat. Sci. 1: $127-131$.

Ahmed M. (1997)- fish for the poor under a rising global demand and changing fishery resources. NAGA: ICLARM quarterly JulyDecember $\mathrm{p}$ 73-76.

Angelescu, V., Gneri, F. S. \& Nani, A., (1958), La merluza del mar argentino (biologiae taxonomia). Secr. Mar. Serv. Hidrog. Nav. Publico, H1004: 1-224.

Babatunde D.O. and Raji A.(2004) Field guide to Nigerian freshwater fishes, second edition.

Bagenal TB,Tesch FW (1978). Age and growth inmethods of assessment of fish production in fresh waters, Ed. Bagenal, T.Oxford Blackwell Scientific Publication. pp.101-136.

Bonga (1999): Globalisation of trade relation and africa trade for fish. Bimonthly bulleting for the West Africa programme improvement of post harvest utilization of artisanal fish catches no. 45 March p8-9

Bolorunduro P.I. (2003) Post harvest loss assessment and adoption of disseminated technologiesin the artisanal fisheries of north western Nigeria: a PhD thesis submitted at Faculty of science,Biological Science Department University of Ibadan.

Lizama M., De los A. P. and Ambrosio, A. M., (2002) Condition factor in nine species of the

\section{Aknowledgement}

We thank the fishermen at Daberam reservoir, Katsina state for there patience and understanding.

\section{Recommendations}

1. Government should declare fishing holiday for at least one calendar year to enable the fish to reproduce and grow to commercially important sizes.

2. The reservoir should be de-silted to increase water volume to prevent loss of fish and other aquatic fauna and flora and also to sustain the current use of the reservoir for extensive irrigation and commercial fishing activities.

3. Freshwater fish species which are predominant in the region but are lacking in the reservoir should be introduce i.e. genus Citharinidae, Bagrus, Aucheglanis, Malaptererus, Mochokidae, Synodontis etc.

4. Further studies should be carried out to determine the level of physico-chemical parameters in the reservoir and its effect on the fish fauna in the reservoir.

Characidae family in the upper Parana river flood plain,Brazil. Braz. J. Biol., 62(1): 113-124,

Delgado C.L. and A.A. Mackenna (1997). Demand for fish in sub-saharan Africa; the past and the future. NACA: ICLARM quarterly JulyDecember. P 79-82.

Ekeng EO (1990). Length-weight relationship and diet composition of Ethmalosa fimbriata (Bowdich) (Pisces; Clupeidae) in Cross-River Estuary, Nigeria. Uni.Cross-River, Nig. B.Sc. Thesis.

Fagade S.O, and Adebisi AA (1979). On the fecundity of Chrysichthylys nigrodigitatus (Lacepede) ofAsejire Dam, Oyo State, Nigeria. Nig J. Nat. Sci. 1: $127-131$.

Frota LO, Costa PAS, Braga AC (2004). Length-weight relationship of marine fishes from the central Brazilian coast. NAGA, ICLARM Q. 27(1\&2): 20-26.

Ikusemiju K (1976). Distribution, reproduction and growth of the catfish, Chrysichthys walkeri (Gunther) in the Lekki Lagoon, Nigeria. J. Fish Biol. 8: 453 - 458.

Le Cren E D (1951) The length-weight relationship and seasonal cycle in gonadal weight and condition in the perch, Perca fluviatilus. J. Anim. Ecol. 20: 201-219.

Pauly D, and Gayanilo Jr. FC (1997). A Bee: An alternative approach to estimating the parameters of a length-weight relationship from length frequency samples and their bulk weights. NAGA ICLARM, Manila,Philippines

Reed W, Burchard j, Hopson A.J, Jennes J. Yaro I. (1967) Fish and fisheries of Northern Nigeria.

Weatherley, A. H., (1972), Growth and ecology of fish populations. Academic Press., London, 293p.

www.fishbase.org. 